\title{
Curcumin Derivative MTH-3 Regulates Palmitate-induced Insulin Resistance in Mouse Myoblast $\mathrm{C}_{2} \mathrm{C}_{12}$ Cells
}

\author{
YU-JEN CHIU ${ }^{1,2,3}$, YU-HSIANG LO ${ }^{4,5}$, JAI-SING YANG $^{5}$, SHENG-CHU KUO $^{6}$ and SHIH-CHANG TSAI ${ }^{4}$ \\ ${ }^{1}$ Division of Plastic and Reconstructive Surgery, Department of Surgery, \\ Taipei Veterans General Hospital, Taipei, Taiwan, R.O.C.; \\ ${ }^{2}$ Department of Surgery, School of Medicine, National Yang Ming Chiao Tung University, Taipei, Taiwan, R.O.C.; \\ ${ }^{3}$ Institute of Clinical Medicine, National Yang Ming Chiao Tung University, Taipei, Taiwan, R.O.C.; \\ ${ }^{4}$ Department of Biological Science and Technology, China Medical University, Taichung, Taiwan, R.O.C.; \\ ${ }^{5}$ Department of Medical Research, China Medical University Hospital, \\ China Medical University, Taichung, Taiwan, R.O.C.; \\ ${ }^{6}$ Chinese Medicinal Research and Development Center, China Medical University Hospital, \\ School of Pharmacy, China Medical University, Taichung, Taiwan, R.O.C.
}

\begin{abstract}
Background/Aim: At present, there are no effective drugs for the treatment of insulin resistance. $M T H-3$, a curcumin derivative, exerts potent anti-cancer effects. The aim of the present study was to explore whether MTH-3 is capable of regulating palmitic acid (PA)-induced insulin resistance in $\mathrm{C}_{2} \mathrm{C}_{12}$ cells. Materials and Methods: Cell viability was examined using the MTT assay. $C_{2} C_{12}$ cells were treated with $P A$ and evaluated for the production of oil droplets using an Oil Red $O$ assay. Glucose uptake was analysed by the 2NBDG assay. Results: Treatment of cells with up to $500 \mu \mathrm{M}$ PA for 24 h or with 5 or $10 \mu M$ MTH-3 had no effect on cell viability. $P A$ induced production of oil droplets in $C_{2} C_{12}$ cells. After adding $M T H-3$, the quantity of oil droplets decreased significantly and glucose uptake recovered. Conclusion: $M T H$ 3 may become an efficient drug for the treatment of insulin resistance and associated diseases.
\end{abstract}

As the prevalence rate of obesity is increasing on a yearly basis, the incidence of obesity-related complications has also risen sharply. Obesity is regarded as a chronic disease and requires long-term observation and management (1). Thus, there is an urgent need to study potential treatments for

This article is freely accessible online.

Correspondence to: Shih-Chang Tsai, Department of Biological Science and Technology, China Medical University, No. 100, Sec. 1, Jing-Mao Road, Taichung 406, Taiwan, R.O.C. Tel: +886 422053366 ext 2518, Fax: +886 422994787, e-mail: sctsai@mail.cmu.edu.tw

Key Words: Curcumin derivative, MTH-3, palmitic acid, insulin resistance, mouse myoblast cells. obesity-related diseases. Obesity refers to a physical condition that has a negative impact on health due to an excessive increase and accumulation in body fat. The primary causes of obesity are excessive energy intake and a sedentary lifestyle; in a small number of cases, the cause is genetic and/or psychological or due to physical diseases. The current treatment methods are behavioral therapy, drug treatment, and bariatric surgery. Behavior therapy is currently the most important treatment method, including diet control and increased exercise (2). The effects of obesity can be roughly divided into two groups. The first effect of obesity is the mental illness/awareness it can cause due to social obstacles/perceptions (3). The second effect of obesity is the metabolic changes including increased risk of diabetes, insulin resistance, metabolic syndrome, gallbladder disease, hypertension, cardiovascular disease, and cancer (4).

Insulin serves a role in regulating glucose metabolism in tissues such as the fat, liver, heart, kidney and in the central nervous system. It can also inhibit glucose production and increase the speed of glucose absorption by muscle and fat cells. Insulin resistance refers to a situation in which liver cells, fat cells, and muscle cells do not respond to normal concentrations of insulin, thus requiring increased production of insulin (5). In individuals with insulin resistance, a physiological concentration of insulin cannot induce absorption of glucose by muscle and fat cells. To compensate for this situation, the pancreas secretes increased quantities of insulin to stimulate these cells to absorb glucose, which results in hyperinsulinemia. Excessive levels of insulin in the blood triggers obesity, as insulin binds receptors on fat cells to inhibit the activity of lipase, which would normally breakdown triglycerides, resulting in the formation of larger fat cells (6). 
Palmitic acid (PA) is one of the most commonly found fatty acids in animals and plants. Butter, cheese, milk, and meat all possess this fatty acid, which is the only fatty acid synthesized in the human body. The liver, adipose tissue, and small intestines in the human body are the primary organs involved in PA synthesis, of which the liver possesses the greatest capacity. Studies have shown that excess lipids affect the levels of free fatty acids, and causes insulin resistance in muscle and liver cells $(7,8)$. PA is one of the most abundant free fatty acids, accounting for 30$35 \%$ of the total free fatty acids in the human blood (9). PA affects the delivery of insulin to hepatocytes and muscle cells in culture $(10,11)$.

Curcumin is extracted and purified from the root of turmeric. In the past, it was often used in traditional pharmacology to treat biliary diseases, loss of appetite, and cough. Curcumin possesses anti-inflammatory, anti-oxidant, and anti-tumor activities (12-14). Studies have shown that curcumin significantly reduces blood sugar and blood lipid levels in diabetic rats $(15,16)$, and significantly improves the symptoms of disordered fat metabolism in diabetic rats (17). Although curcumin has been shown to possess a favorable therapeutic effect on several diseases (18), its shortcomings are the poor hydrophilicity and low bioavailability. The curcumin derivative, MTH-3, has thus been developed and studied with the aim of improving hydrophilicity (19). MTH-3 has also been shown to be more effective with regards to anti-cancer effects against triplenegative breast cancer in animal experiments compared with curcumin (20). However, the mechanism by which MTH-3 regulates insulin resistance caused by free fatty acid metabolism remains unclear. The aim of the present study was to explore the effects and mechanism of MTH-3 on insulin resistance in $\mathrm{C}_{2} \mathrm{C}_{12}$ cells.

\section{Materials and Methods}

Cell differentiation. Cell differentiation was assayed as described previously by Bajaj et al. (21). Briefly, cells were plated at a density of $2 \times 10^{5}$ cells $/ \mathrm{ml}$ in each well of a 6 -well plate for $24 \mathrm{~h}$. Cells were cultured in DMEM supplemented with $2 \%$ horse serum, and the medium was changed every day for 5 days. The formation of a muscular tube represented the completion of differentiation.

MTT assay. Cell viability was assessed using an MTT assay, as previously described (22). Briefly, cells were seeded at a density of $2 \times 10^{5}$ cells $/ \mathrm{ml}$ in each well of a 96 -well plate (Thermo Fisher Scientific, Inc., Waltham, MA, USA), cultured for $24 \mathrm{~h}$, and then treated with different concentrations $(0,5$ and $10 \mu \mathrm{M})$ of MTH-3 or different concentrations of PA $(0,100,200,300,400$ or 500 $\mu \mathrm{M})$ for $24 \mathrm{~h}$. MTT was added to each well at a final concentration of $0.5 \mathrm{mg} / \mathrm{ml}$, and incubated at $37^{\circ} \mathrm{C}$ for $3 \mathrm{~h}$. The supernatant was discarded and DMSO was added to dissolve the formazan crystals. The absorbance at $595 \mathrm{~nm}$ was recorded using a microplate reader, and control absorbance was normalized to
$100 \%$. A total of six wells per condition were used, across at least four independent experiments.

Oil Red O staining. Cells were cultured in DMEM containing 2\% horse serum, and medium was changed every day for 5 days. After 5 days, the culture medium was aspirated, and different concentrations $(0,100,200,300,400$ or $500 \mu \mathrm{M})$ of PA were added for $24 \mathrm{~h}$. Cells were washed with PBS and then $1 \mathrm{ml}$ of $10 \%$ formalin was added to each well for $1 \mathrm{~h}$. Cells were washed with $\mathrm{ddH}_{2} \mathrm{O}$ and then $1 \mathrm{ml} 60 \%$ isopropanol was added to each well. After isopropanol was aspirated, cells were stained with Oil-Red-O at room temperature for $2 \mathrm{~h}$ in the dark and then observed using an inverted microscope at $100 \times$ magnification (23).

Glucose uptake assay. The $\mathrm{C}_{2} \mathrm{C}_{12}$ myotubes were treated with 0.4 $\mathrm{mM}$ PA and MTH-3 (5 and $10 \mu \mathrm{M})$ simultaneously for $24 \mathrm{~h}$. The cells were washed three times with PBS, and subsequently incubated in the presence or absence of $100 \mathrm{nM}$ insulin for $10 \mathrm{~min}$ before the addition of $20 \mu \mathrm{l}$ 2-NBDG $(5 \mathrm{mM})$ for $2 \mathrm{~h}$ at $37^{\circ} \mathrm{C}$. Subsequently, $30 \mu \mathrm{l}$ cell suspension was immediately loaded into a 2-chamber slide (NC-Slide A2; ChemoMetec A/S, Allerod, Denmark) for analysis on the NucleoCounter NC-3000 using the built-in caspase assay program (24).

RNA extract. Total RNA was isolated using TRIzol $^{\circledR}$ reagent (Invitrogen; Thermo Fisher Scientific, Inc.) according to the manufacturer's protocol, as described previously (25). Briefly, $2 \times 10^{6}$ cells for each treatment were harvested and mixed with $1 \mathrm{ml}$ TRIzol ${ }^{\circledR}$ reagent at room temperature for $5 \mathrm{~min}$. To each tube, 0.2 $\mathrm{ml}$ chloroform was added, and centrifuged at $12,000 \times \mathrm{g}$ for $15 \mathrm{~min}$ at $4^{\circ} \mathrm{C}$. The supernatant was collected and mixed with $0.5 \mathrm{ml}$ isopropanol for $10 \mathrm{~min}$. This was further centrifuged at $12,000 \times g$ for $15 \mathrm{~min}$ at $4^{\circ} \mathrm{C}$. RNA pellets were dissolved in $100 \mu \mathrm{l}$ DEPCtreated $\mathrm{H}_{2} \mathrm{O}$.

Quantitative (q)PCR. qPCR was performed using a TaKaRa One Step SYBR Ex Taq ${ }^{\text {TM }}$ qRT-PCR kit (Takara Bio, Inc., Shiga, Japan) as described previously (25) in a QuantStudio ${ }^{\mathrm{TM}} 3$ Real-Time PCR system (Thermo Fisher Scientific, Inc.). Relative expression levels of target genes were normalized to $\beta$-actin. The relative expression levels of mRNA are presented as the mean \pm standard deviation of duplicates. The sequences of the primers used for qPCR were: GAPDH, forward, 5'-gagtgtttcctcgtcccgtaga-3' and reverse, 5' -gtgaccaggcgeccaata-3'; glucose transporter 4 (GLUT4) forward, 5'-caatggttgggaaggaaaagg-3' and reverse, 5'-ggcgcccccaaca-3'; Myogenin forward, 5'accctacagacgcccacaatc-3' and reverse, 5'-acatatcctccaccgtgatgct-3'; transcription factor EB (TFEB) forward, 5' -gcggcagaagaaagacaatcac3' and reverse, 5' -tgatccggtcattgatgttgaa-3'; peroxisome proliferatoractivated receptor- $\gamma$ (PPAR- $\gamma)$ coactivator $1-\alpha(\mathrm{PGC} 1 \alpha)$ forward, 5'ggcacgcagccctattca-3' and reverse, 5'-tctcgacacggagagttaaagga-3'; and PPAR $\gamma$ forward, 5'-accacagttgatttctccagcatt-3' and reverse, 5'ccattgggtcagctcttgtga- $3^{\prime}$.

Western blotting. Western blotting was performed as described previously (26). Briefly, $100 \mu \mathrm{g}$ protein prepared form each sample was used for western blot analysis. The primary antibodies used were: Anti-GLUT4 (cat. no. GTX79317; GeneTex Inc., Irvine, CA, USA) and anti- $\beta$-Actin (cat. no. GTX629630; GeneTex Inc.). Protein bands were semi-quantified using ImageJ 1.4 (National Institutes of Health, Bethesda, MD, USA). 
A

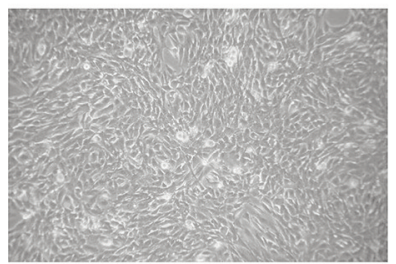

2\% Horse serum ( 0 h)

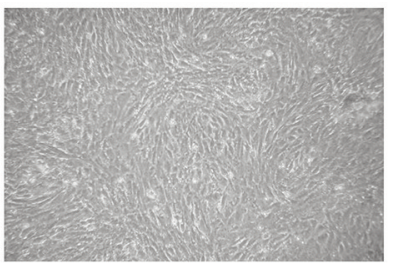

2\% Horse serum (48 h)

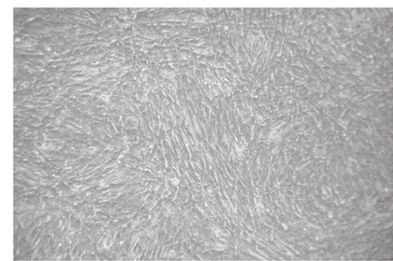

$2 \%$ Horse serum $(96 \mathrm{~h})$
B

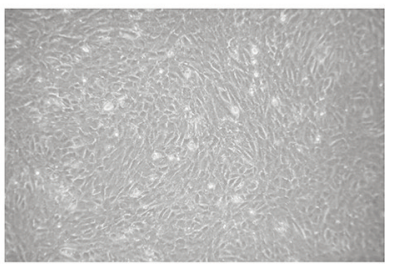

2\% Horse serum (24 h)

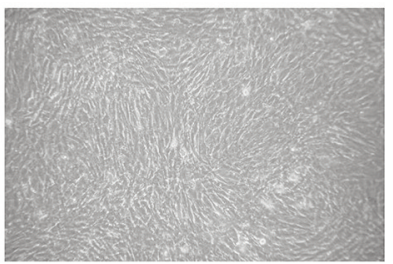

2\% Horse serum (72 h)

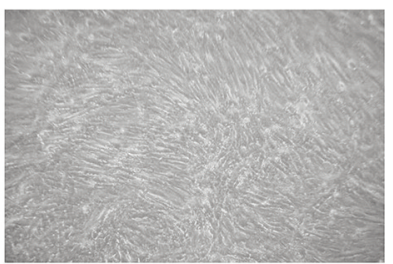

2\% Horse serum (120 h)

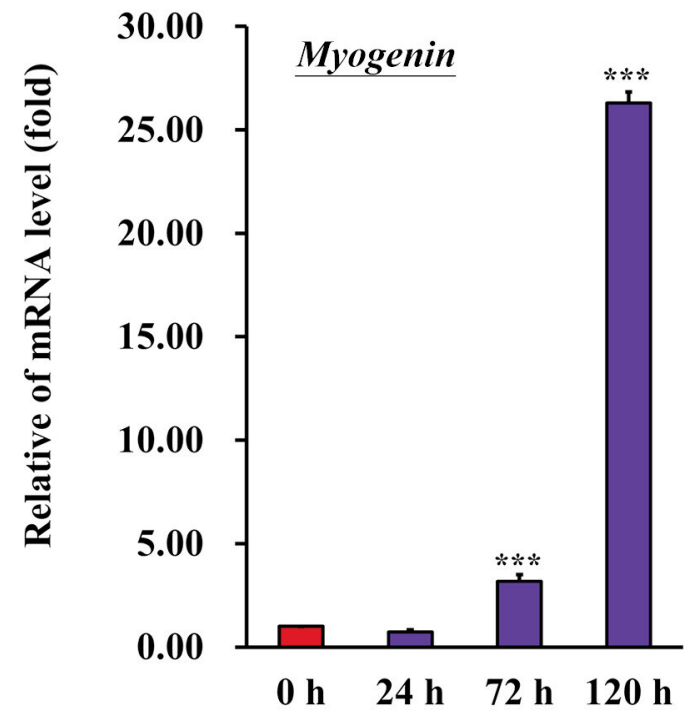

Figure 1. Differentiation of $C_{2} C_{12}$ cells. (A) Changes in morphology of $C_{2} C_{12}$ cells. $C_{2} C_{12}$ were cultured in DMEM supplemented with $2 \%$ horse serum to induce differentiation. Culture medium was changed daily. Formation of myotubes was observed under an inverted microscope daily. (B) mRNA expression of myogenin, a biological indicator of $C_{2} C_{12}$ differentiation, was evaluated. $* * * p<0.001$ vs. control.

Statistical analysis. The experimental data are presented as the mean \pm standard deviation. A one-way ANOVA was used for multiple comparisons. $p<0.05$ was considered to indicate a statistically significant difference. Data were analyzed using GraphPad Prism version 7 (GraphPad Software, Inc., San Diego, CA, USA).

\section{Results}

Effect of PA on $\mathrm{C}_{2} \mathrm{C}_{12}$ cell survival. To establish a cell model for evaluating $\mathrm{C}_{2} \mathrm{C}_{12}$ differentiation, $\mathrm{C}_{2} \mathrm{C}_{12}$ cells were cultured in a differentiation medium. $\mathrm{C}_{2} \mathrm{C}_{12}$ cells differentiated after cells were cultured for 5 days in the differentiation medium (Figure 1A). Myotubes were formed that were observed under an inverted microscope. Myogenin expression, a biological indicator of $\mathrm{C}_{2} \mathrm{C}_{12}$ differentiation, was evaluated by reverse transcription (RT)-qPCR (Figure 1B). Myogenin expression was significantly increased after cells were cultured for 5 days in the differentiation medium. To examine whether PA affected cell viability in $\mathrm{C}_{2} \mathrm{C}_{12}$ cells, an MTT assay was performed. $\mathrm{C}_{2} \mathrm{C}_{12}$ myotubes cells were treated with $0-500 \mu \mathrm{M}$ PA (Figure $2 \mathrm{~A}$ ) for $24 \mathrm{~h}$ to examine cell viability (Figure $2 \mathrm{~B}$ ). Cell viability was decreased when
A

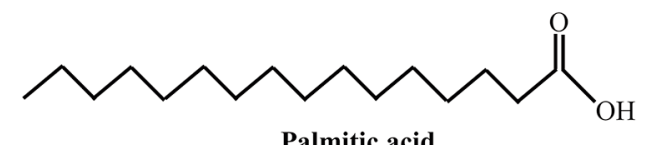

B

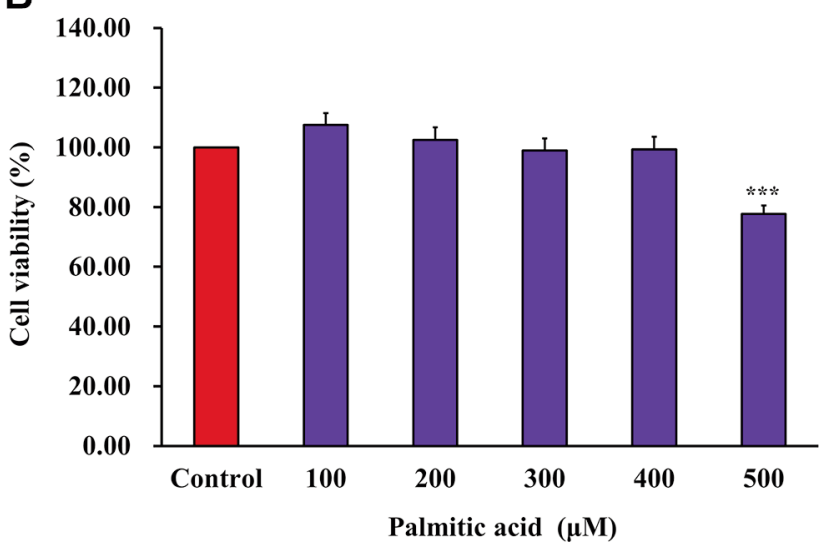

Figure 2. Effect of palmitic acid (PA) on $C_{2} C_{12}$ cell survival. (A) Chemical structure of PA. (B) $C_{2} C_{12}$ cells were treated with 0, 100, 200, 300, 400, or $500 \mu \mathrm{M}$ PA for $24 \mathrm{~h}$. Cell viability was determined using an MTT assay. ***p<0.001 vs. control. PA: Palmitic acid. 
A

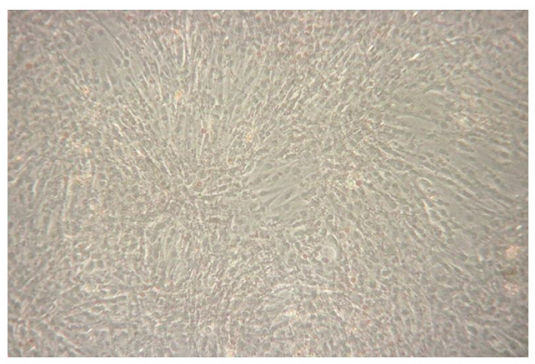

Control

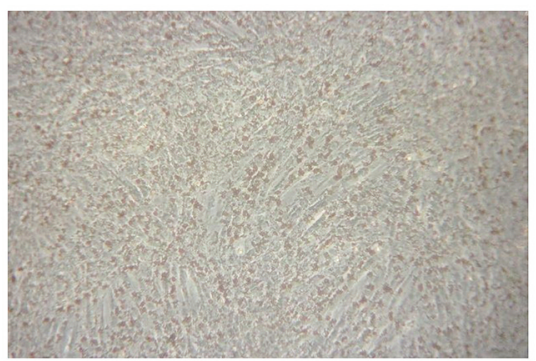

Palmitic acid $(200 \mu \mathrm{M})$

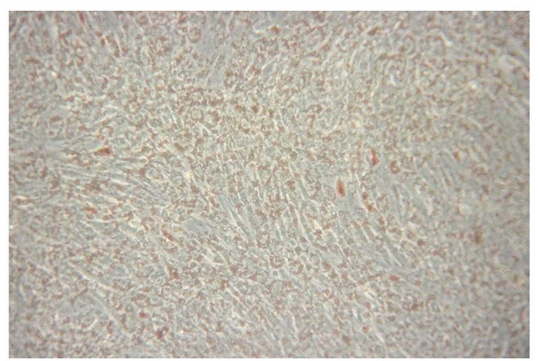

Palmitic acid $(400 \mu \mathrm{M})$

B

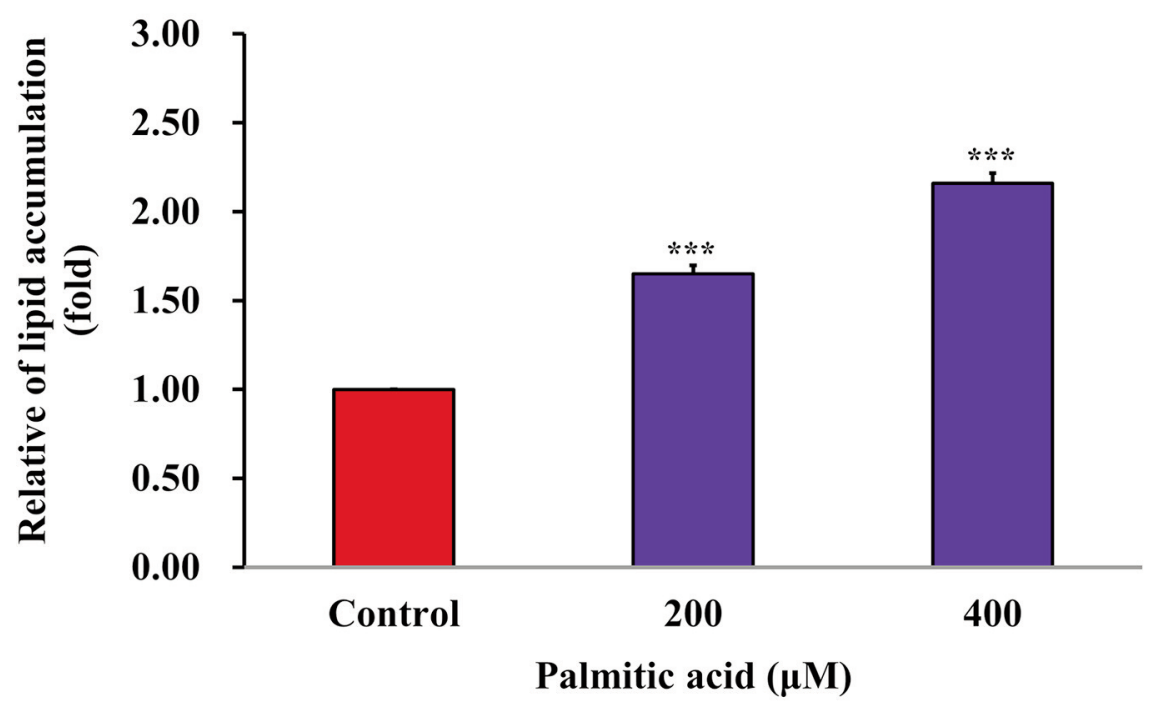

Figure 3. Palmitic acid (PA) induces the production of oil droplets in $C_{2} C_{12}$ cells. (A) $C_{2} C_{12}$ cells were treated with 0,200 or $400 \mu M$ PA for 24 h. Production of oil droplets was assayed using Oil Red O staining. (B) Fold change in the treated group compared with the control group was calculated. ${ }^{* * *} p<0.001 \mathrm{vs.}$ control.

cells were treated with $500 \mu \mathrm{M}$ PA. PA at a concentration of 100-400 $\mu \mathrm{M}$ had no effect on $\mathrm{C}_{2} \mathrm{C}_{12}$ myotube cells. Therefore, PA concentrations $<400 \mu \mathrm{M}$ were used in the present study.

$P A$ induces the production of oil droplets in $C_{2} C_{12}$ cells. Lipid droplets contain neutral lipids, primarily triglycerides, and cholesterol esters. Excessive accumulation of lipid droplets in cells may be an indicator of metabolic defects or pathogenesis. Oil Red $\mathrm{O}$ binds to triglycerides, lipids and lipoproteins, and dyes them red. The quantity of oil droplets was determined using Oil Red O. $\mathrm{C}_{2} \mathrm{C}_{12}$ cells were treated with 200 and $400 \mu \mathrm{M}$ PA for $24 \mathrm{~h}$. PA treated $\mathrm{C}_{2} \mathrm{C}_{12}$ cells produced more oil droplets than the control group (Figure $3 \mathrm{~A}$ and B).
PA down-regulates GLUT4 expression in $C_{2} C_{12}$ cells. The primary glucose absorption receptor in muscle cells is GLUT4. To examine whether PA affected the function of GLUT4 to alter insulin resistance, the protein and mRNA expression levels of GLUT4 were analyzed using western blotting and RT-qPCR, respectively. The protein and mRNA expression levels of GLUT4 were significantly reduced in PA-treated $\mathrm{C}_{2} \mathrm{C}_{12}$ cells (Figure $4 \mathrm{~A}$ and $\mathrm{B}$ ). These results highlight a potential mechanism for the insulin resistance in PA-treated $\mathrm{C}_{2} \mathrm{C}_{12}$ cells.

MTH-3 reduces the effect of $P A$ on the production of oil droplets in $\mathrm{C}_{2} \mathrm{C}_{12}$ cells. $\mathrm{C}_{2} \mathrm{C}_{12}$ myotubes cells were treated with 5 or $10 \mu \mathrm{M}$ MTH-3 (Figure 5A) for $24 \mathrm{~h}$ to examine cell viability using an MTT assay (Figure 5B). MTH-3 at a 
A
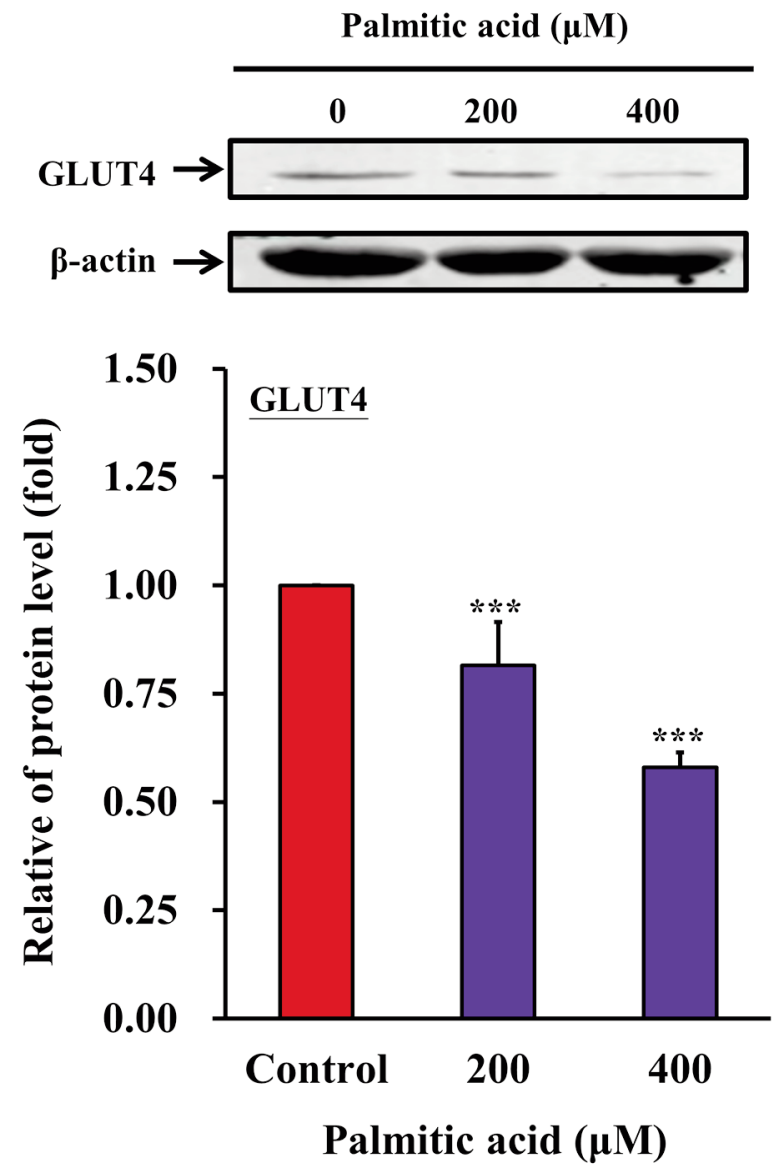

B

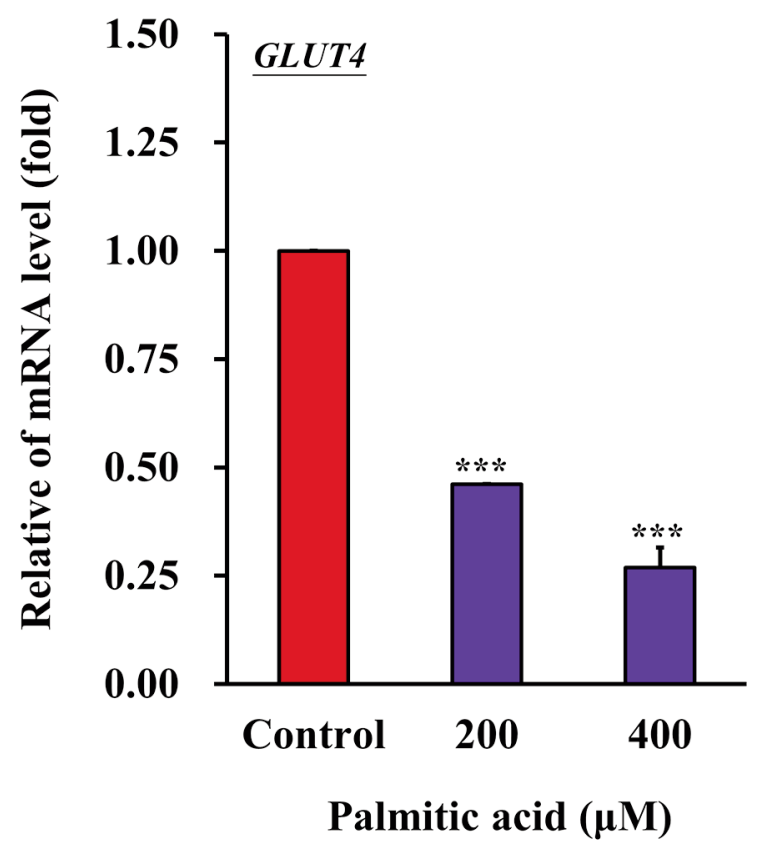

Figure 4. PA down-regulates GLUT4 expression in $C_{2} C_{12}$ cells. $C_{2} C_{12}$ cells were treated with 0,200 or $400 \mu M$ PA for 24 h. (A) Protein and (B) RNA expression levels of GLUT4 were analyzed by western blotting and reverse transcription-quantitative PCR, respectively. ***p<0.001 vs. control. GLUT4: Glucose transporter 4.

concentration of 5 or $10 \mu \mathrm{M}$ had no effect on $\mathrm{C}_{2} \mathrm{C}_{12}$ cells. To investigate whether $\mathrm{MTH}-3$ reduced the production of oil droplets in PA-stimulated $\mathrm{C}_{2} \mathrm{C}_{12}$ cells, Oil Red $\mathrm{O}$ staining was performed. $\mathrm{C}_{2} \mathrm{C}_{12}$ cells were treated with MTH-3 (0, 5 or $10 \mu \mathrm{M})$ in the absence or presence of PA $(400 \mu \mathrm{M})$ for 24 $\mathrm{h}$. The results showed that MTH-3 reduced the production of oil droplets in PA-treated $\mathrm{C}_{2} \mathrm{C}_{12}$ cells (Figure 6).

MTH-3 ameliorates glucose uptake in PA-treated $C_{2} C_{12}$ cells. To investigate whether MTH-3 caused insulin resistance, 2-NBDG was used to detect glucose uptake in PA-stimulated $\mathrm{C}_{2} \mathrm{C}_{12}$ cells. $\mathrm{C}_{2} \mathrm{C}_{12}$ cells were pre-treated with $100 \mathrm{nM}$ insulin for $10 \mathrm{~min}$, and subsequently treated with MTH-3 $(0,5$ or $10 \mu \mathrm{M})$ in the absence or presence of PA $(400 \mu \mathrm{M})$ for $24 \mathrm{~h}$. 2-NBDG was added to cells to analyze glucose uptake. As shown in Figure 7, glucose uptake was significantly increased in the MTH-3 treated $\mathrm{C}_{2} \mathrm{C}_{12}$ cells.
$M T H-3$ reverses the expression of TFEB and PPAR- $\gamma$ in PAtreated $C_{2} C_{12}$ cells. To characterize the signaling pathways involved, the expression of TFEB and PPAR $-\gamma$ were determined. TFEB is the primary transcription factor in lysosomal biosynthesis. In a state of starvation, TFEB increases autophagy, and thus increases fat metabolism. In the liver, TFEB regulates genes involved in lipid catabolism, fatty acid oxidation, and ketone synthesis (27). TFEB also plays a key role in mediating insulin sensitivity, glucose stabilization, lipid oxidation, and mitochondrial function (28). $\mathrm{C}_{2} \mathrm{C}_{12}$ cells were treated with 5 and $10 \mu \mathrm{M}$ MTH-3 in the absence or presence of PA $(400 \mu \mathrm{M})$ for $24 \mathrm{~h}$, and RNA was subsequently extracted. Expression of TFEB was determined by RT-qPCR. TFEB expression was significantly increased in the MTH-3-treated $\mathrm{C}_{2} \mathrm{C}_{12}$ cells (Figure 8A). PPARs are a group of nuclear proteins that function as transcription factors to regulate gene expression. PPARs 
A<smiles>COc1cc(/C=C/C(=O)/C=C(O)/C=C/c2ccc(OC(=O)C(C)(CO)CO)c(OC)c2)ccc1OC(=O)C(C)(CO)CO</smiles>

B

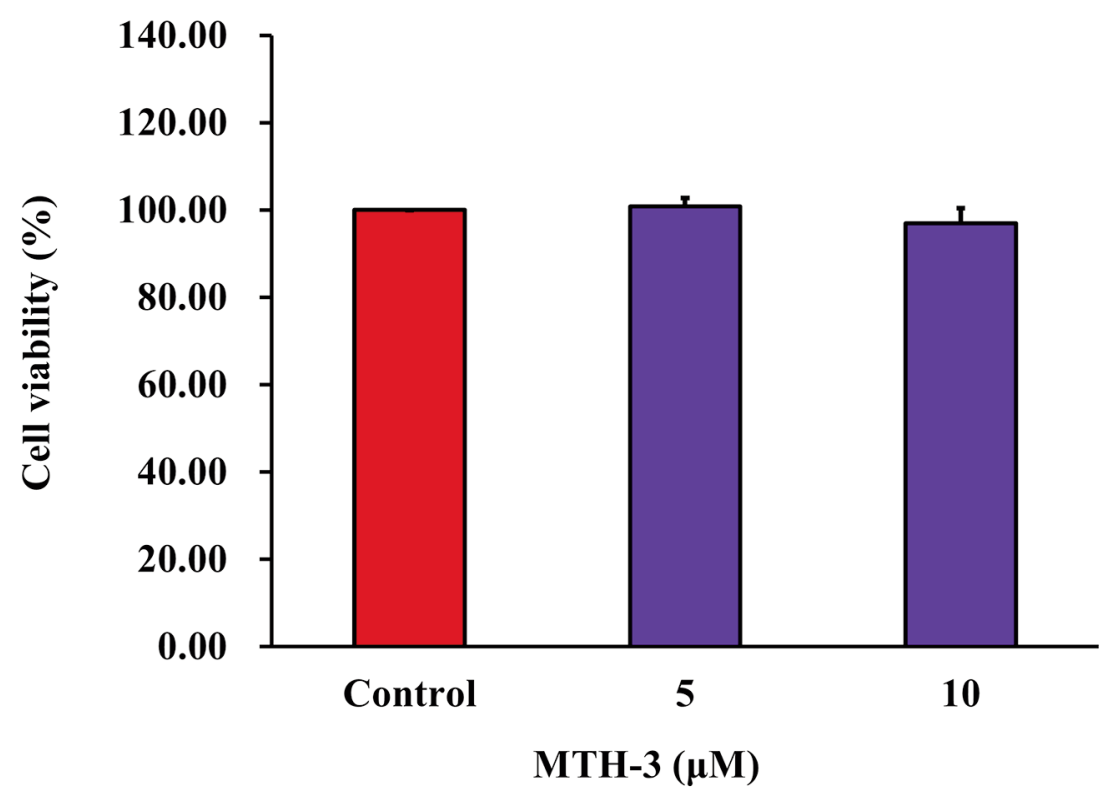

Figure 5. Effect of MTH-3 on $C_{2} C_{12}$ cell survival. (A) Chemical structure of MTH-3. (B) $C_{2} C_{12}$ cells were treated with 0, 5 or $10 \mu M$ MTH-3 for $24 \mathrm{~h}$. Cell viability was determined using an MTT assay. MTH-3 at a concentration of 5 and $10 \mu M$ had no effect on the viability of $C_{2} C_{12}$ cells.

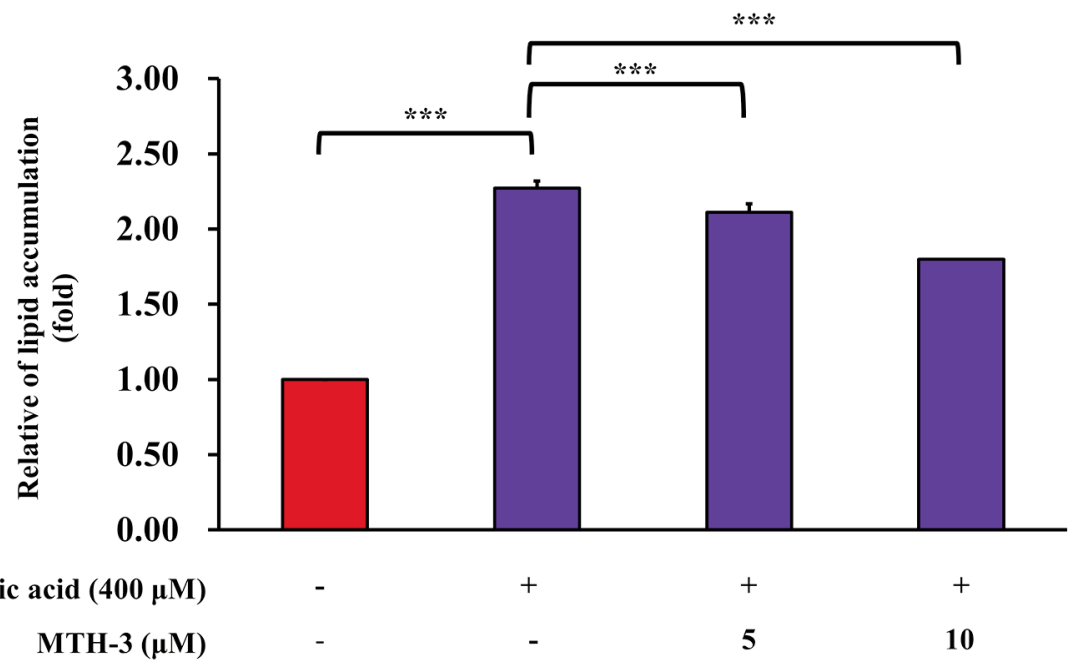

Figure 6. MTH-3 reduces the effect of palmitic acid (PA) on the production of oil droplets in $C_{2} C_{12}$ cells. $C_{2} C_{12}$ cells were treated with MTH-3 ( 0 , 5 and $10 \mu \mathrm{M})$ in the absence or presence of PA $(400 \mu \mathrm{M})$ for $24 \mathrm{~h}$. The production of oil droplets was assayed using Oil Red $O$ staining. Fold change was calculated in the treated groups compared with the control group. ${ }^{* * *} p<0.001$ vs. untreated group. 
A
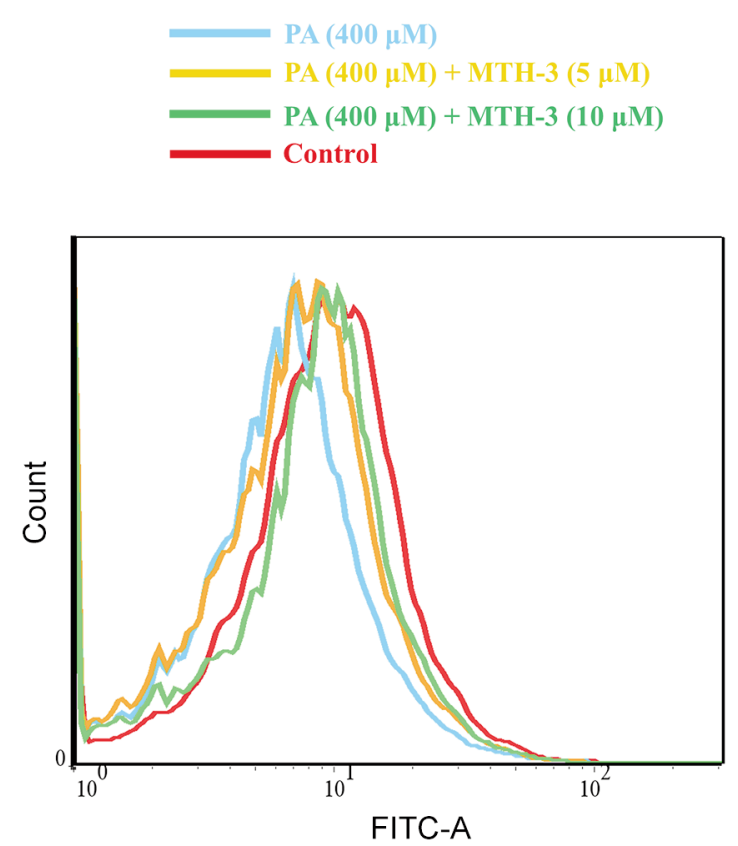

B

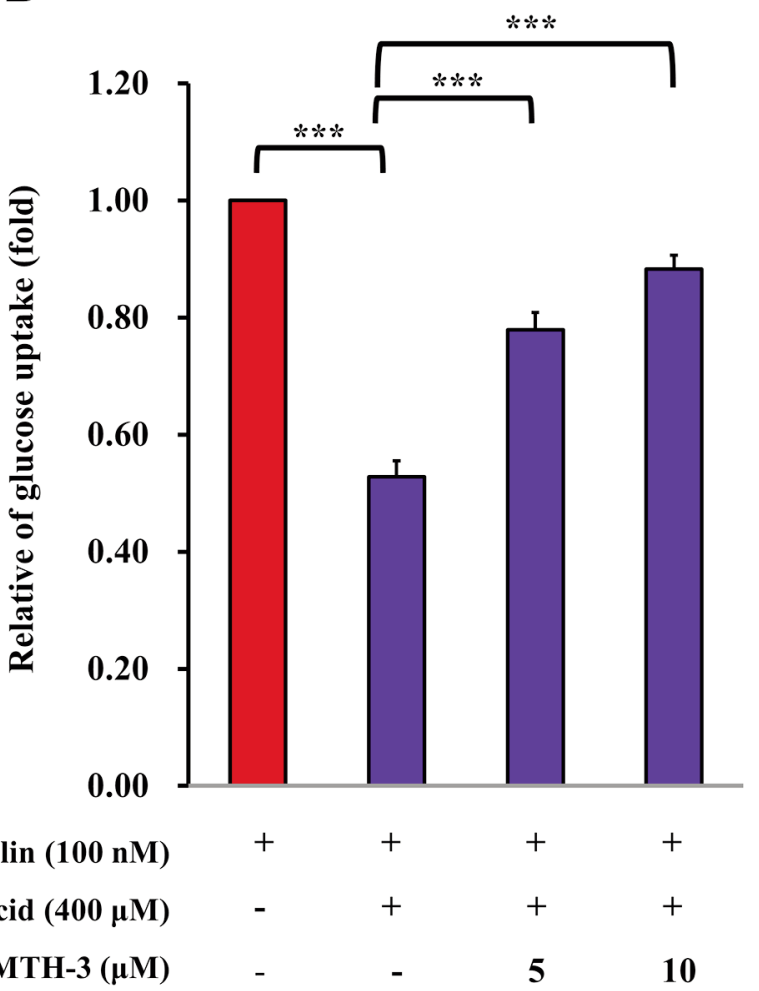

Figure 7. MTH-3 ameliorates glucose uptake in palmitic acid (PA)-treated $C_{2} C_{12}$ cells. (A) $C_{2} C_{12}$ cells were pre-treated with $100 \mathrm{nM}$ insulin for 10 min. $C_{2} C_{12}$ cells were subsequently treated with MTH-3 $(0,5$ and $10 \mu M)$ in the absence or presence of PA (400 $\left.\mu M\right)$ for 24 h. 2-NBDG was added to cells to assess glucose uptake. (B) Relative changes were calculated in the treated group compared with the untreated group. $* * * p<0.001$ vs. untreated group.

serve a key role in cell differentiation, metabolism and cancer (29). There are three types of PPARs, namely PPAR $\alpha, \beta$ and $\gamma$. These three types are expressed in different tissues and reflect different physiological functions. Amongst these, PPAR- $\gamma$ plays an important regulatory role in insulin sensitivity $(30) . \mathrm{C}_{2} \mathrm{C}_{12}$ cells were treated with 5 and $10 \mu \mathrm{M}$ MTH-3 in the absence or presence of PA $(400 \mu \mathrm{M})$ for $24 \mathrm{~h}$ and RNA was subsequently extracted. Expression of PPAR- $\gamma$ was determined by RTqPCR. PPAR- $\gamma$ expression was significantly increased in the MTH-3-treated $\mathrm{C}_{2} \mathrm{C}_{12}$ cells (Figure $8 \mathrm{~B}$ ). Taken together, TFEB and PPAR- $\gamma$ expression was significantly increased in the MTH-3-treated $\mathrm{C}_{2} \mathrm{C}_{12}$ cells.

\section{Discussion}

Skeletal myoblasts are the optimal cells for studying muscle cell proliferation and differentiation in vitro $(31,32)$. When skeletal myoblasts are cultured in medium supplemented with $10 \%$ fetal calf serum, they continue to proliferate. However, when they are cultured in medium supplemented with $2 \%$ horse serum, the cells readily fuse and form myotubes $(31,33)$. In the present study, the $\mathrm{C}_{2} \mathrm{C}_{12}$ cells were an immortalized mouse myoblast cell line, and a wellestablished in vitro model for studying muscle regeneration and differentiation. In the present study, $\mathrm{C}_{2} \mathrm{C}_{12}$ cells were used to study myoblast proliferation and differentiation. During $\mathrm{C}_{2} \mathrm{C}_{12}$ cell differentiation, myoblasts undergo remodeling to form mature myotubes, and exhibit increased myogenin mRNA expression $(34,35)$. As shown in Figure $1 \mathrm{~A}, 2 \%$ horse serum medium triggered myogenic differentiation after 72,96 , and $120 \mathrm{~h}$ of induction, and the cells that formed the myotubes presented considerable numbers of fused myotubes. Myogenin expression at the mRNA level was increased after 72 and $120 \mathrm{~h}$ of culture with $2 \%$ horse serum. Thus, it was demonstrated that $2 \%$ horse serum induced myogenic differentiation of $\mathrm{C}_{2} \mathrm{C}_{12}$ cells.

Insulin resistance is one of the major physiological characteristics of a type II diabetes mellitus (T2D) phenotype (36-38). High levels of free fatty acids in the plasma are associated with insulin resistance in T2D $(39,40)$. PA is a saturated fatty acid that has been implicated in the development of T2D (41). Excess transpiration of PA to the skeletal muscle is implicated in the development of insulin 
A
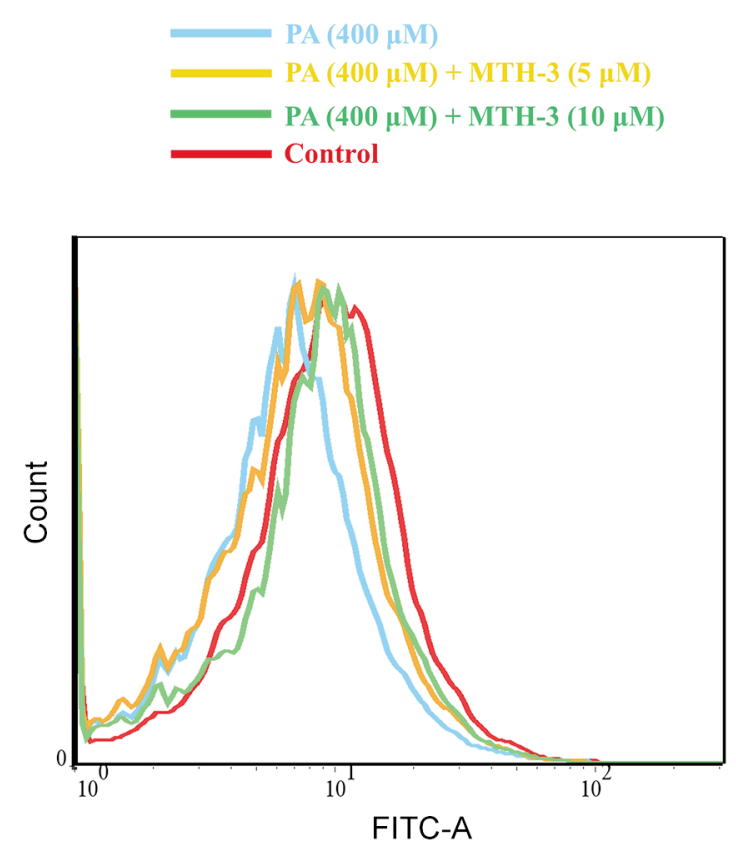

B

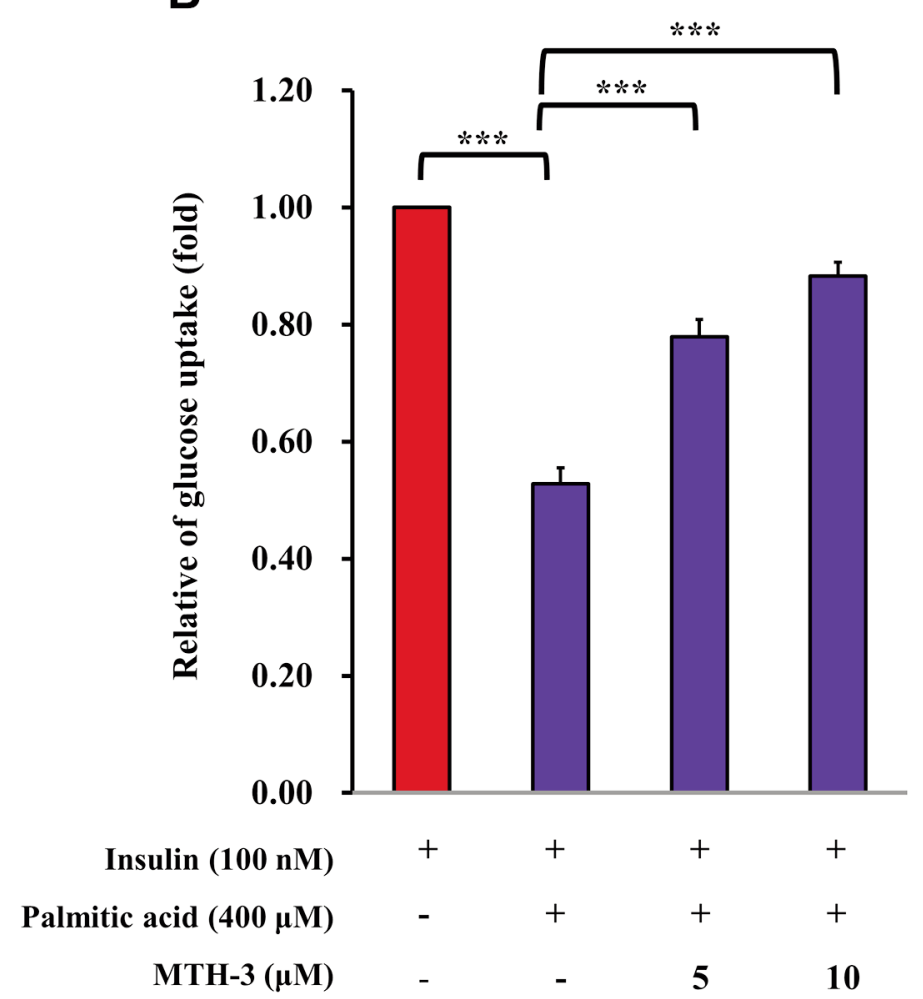

Figure 8. MTH-3 decreases the expression of TFEB and PPAR- $\gamma$ in PA-treated $C_{2} C_{12}$ cells. $C_{2} C_{12}$ cells were treated with MTH-3 (0, 5 and $10 \mu M$ ) in the absence or presence of PA $(400 \mu M)$ for $24 h$, and RNA was subsequently extracted. Expression of (A) TFEB and (B) PPAR- $\gamma$ was determined by reverse transcription-quantitative PCR. Relative changes were calculated in the treated group compared with the untreated group. $* * * p<0.001$ vs. control. TFEB: Transcription factor EB; PPAR $\gamma$ : peroxisome proliferator-activated receptor- $\gamma$; PA: palmitic acid.

resistance, resulting from lipid oversupply to skeletal muscles (42-44). In the present study, 100, 200, 300, 400, and $500 \mu \mathrm{M}$ PA was used to treat $\mathrm{C}_{2} \mathrm{C}_{12}$ cells cultured with $2 \%$ horse serum supplemented medium for up to $120 \mathrm{~h}$. Treatment for $24 \mathrm{~h}$ with 100-400 $\mu \mathrm{M}$ PA did not affect cell viability. PA-induced intracellular lipid accumulation as determined using Oil Red $\mathrm{O}$ staining when cells were treated with 200 and $400 \mu \mathrm{M}$ PA. It has been reported that GLUT4 protein is highly expressed in $\mathrm{C}_{2} \mathrm{C}_{12}$ cells, which can be used in the investigation of glucose uptake and insulin resistance mechanisms $(45,46)$. In the present study, it was shown that GLUT4 mRNA and protein expression levels were reduced in cells treated with 200 and $400 \mu \mathrm{M}$ PA. It was hypothesized that PA induced intracellular lipid droplet deposition and increased insulin resistance in $\mathrm{C}_{2} \mathrm{C}_{12}$ myotubes. Thus, an in vitro model of insulin resistance using $\mathrm{C}_{2} \mathrm{C}_{12}$ myotubes was successfully established.

Curcumin, a constituent compound of Curcuma longa plants, has various pharmacological properties, including anti-oxidant, anti-inflammatory, anti-bacterial, anti-viral, anti-cancer, and anti-diabetic properties (47, 48). A clinical study showed that curcumin was safe even at doses of up to
$8 \mathrm{~g}$ per day (20). However, the pharmacokinetic studies of curcumin on animal and human models have demonstrated poor absorption in the gastrointestinal tract $(49,50)$. Low systemic bioavailability of curcumin prevents a suitable concentration reaching the target tissues to achieve its pharmacological effects (20). To overcome its poor bioavailability and increase curcumin absorption in the gastrointestinal tract, a novel curcumin derivative, (1E,3Z,6E)-3-hydroxy-5-oxohepta-1,3,6-triene-1,7-diyl)bis (2-methoxy-4,1-phenylene)-bis (3-hydroxy-2hydroxymethyl)-2-methyl propanoate, referred to as MTH-3 in the present study, was established. A previous study demonstrated that MTH-3 inhibits proliferation of triplenegative breast adenocarcinoma cells and induces cell death in vitro and in vivo (20). In our previous study, it was also demonstrated that MTH-3 inhibits triple-negative breast adenocarcinoma cell metastasis via the MAPK/ERK/AKT signaling pathway (51). MTH-3 was effective against several different cancer cell lines and exerted only limited toxicity on physiologically healthy cells (19). To the best of our knowledge, the present study is the first to demonstrate that MTH-3 regulates PA-induced insulin resistance in mouse 
myoblast $\mathrm{C}_{2} \mathrm{C}_{12}$ cells. The results showed that 5 and $10 \mu \mathrm{M}$ MTH-3 treatment for $24 \mathrm{~h}$ did not affect cell viability. MTH3 reduced intracellular lipid accumulation and glucose uptake when 5 and $10 \mu \mathrm{M}$ MTH-3 was administered in $\mathrm{C}_{2} \mathrm{C}_{12}$ cells treated with PA to induce insulin resistance.

TFEB is a transcription factor, and acts as a primary regulator of autophagy, lysosomal genesis, lipid and energy metabolism, and the immune response (52-55). Previous studies demonstrated that TFEB can advance neurodegenerative diseases, such as Parkinson's disease and Huntington's disease $(56,57)$. TFEB also serves an important role in the metabolic response to starvation (58-60). Absence of TFEB results in impairment of lipid catabolism, and TFEB over-expression rescues obesity and the associated metabolic syndrome. It was reported that TFEB regulated insulin resistance and a PPAR $\alpha$ agonist (Fenofibrate) reduces hepatic fat accumulation through the upregulation of TFEB-mediated lipophagy $(28,61,62)$. In addition, Verma et al. (63) demonstrated that PPAR $\gamma$ expression also regulated insulin resistance in $\mathrm{C}_{2} \mathrm{C}_{12}$ skeletal muscle cells. MTH-3 induced TFEB and PPAR $\gamma$ mRNA expression when cells were treated with 5 or $10 \mu \mathrm{M}$ MTH-3 in PA-induced insulin resistant $\mathrm{C}_{2} \mathrm{C}_{12}$ cells. These results suggested that MTH3 relieves $\mathrm{PA}$-induced intracellular lipid droplet deposition and increases insulin resistance in $\mathrm{C}_{2} \mathrm{C}_{12}$ myotubes through upregulating TFEB and PPAR $\gamma$ gene expression.

In conclusion, it was shown that PA induced intracellular lipid droplet deposition and increased insulin resistance in $\mathrm{C}_{2} \mathrm{C}_{12}$ myotubes. MTH-3 improved PA-induced-insulin resistance in $\mathrm{C}_{2} \mathrm{C}_{12}$ cells through increased TFEB and PPAR $\gamma$ expression at the mRNA level. Based on these results, MTH-3 may be considered a promising therapeutic strategy for the treatment of T2D.

\section{Funding}

The present study was supported in part by the China Medical University Hospital (grant no. DMR-110-155), China Medical University (grant no. CMU103-S-16 and MOST 106-2314-B-039046), Taipei Veterans General hospital (grant no. V110B-038), Yen Tjing Ling Medical Foundation (grant no. CI-110-6) and the Chinese Medicine Research Center, China Medical University from The Featured Areas Research Center Program within the framework of the Higher Education Sprout Project by the Ministry of Education (MOE) in Taiwan, R.O.C.

\section{Conflicts of Interest}

All the Authors have declared no conflicts of interest in relation to this study.

\section{Authors' Contributions}

YJC, YSL, JSY and SCT conceived and designed the study. YJC, YSL and SCT performed the experiments. YSL, JSY and SCT analyzed the data. YJC, JSY SCK and SCT wrote and modified the manuscript. All the Authors read and approved the manuscript. All Authors confirm the authenticity of all the raw data.

\section{Acknowledgements}

The Authors would like to thank the Office of Research \& Development at China Medical University, Taichung, Taiwan, R.O.C. for allowing the use of the Medical Research Core Facilities to perform the experiments and data analysis.

\section{References}

1 Brown JC, Carson TL, Thompson HJ and Agurs-Collins T: The triple health threat of diabetes, obesity, and cancer-epidemiology, disparities, mechanisms, and interventions. Obesity (Silver Spring) 29(6): 954-959, 2021. PMID: 34029445. DOI: 10.1002/oby.23161

2 Pan XF, Wang L and Pan A: Epidemiology and determinants of obesity in China. Lancet Diabetes Endocrinol 9(6): 373-392, 2021. PMID: 34022156. DOI: 10.1016/S2213-8587(21)00045-0

3 Fontaine KR, Cheskin LJ and Barofsky I: Health-related quality of life in obese persons seeking treatment. J Fam Pract 43(3): 265-270, 1996. PMID: 8797754.

4 Sivasubramanian R, Malhotra S, Fitch AK and Singhal V: Obesity and metabolic care of children of South Asian ethnicity in western society. Children (Basel) 8(6): 447, 2021. PMID: 34070381. DOI: $10.3390 /$ children8060447

5 Bratanova-Tochkova TK, Cheng H, Daniel S, Gunawardana S, Liu YJ, Mulvaney-Musa J, Schermerhorn T, Straub SG, Yajima $\mathrm{H}$ and Sharp GW: Triggering and augmentation mechanisms, granule pools, and biphasic insulin secretion. Diabetes 51 Suppl 1: S83-S90, 2002. PMID: 11815463. DOI: 10.2337/diabetes. 51.2007.s83

6 DeFronzo RA: Lilly lecture 1987. The triumvirate: beta-cell, muscle, liver. A collusion responsible for NIDDM. Diabetes 37(6): 667-687, 1988. PMID: 3289989. DOI: 10.2337/diab. 37.6 .667

7 Kahn BB and Flier JS: Obesity and insulin resistance. J Clin Invest 106(4): 473-481, 2000. PMID: 10953022. DOI: 10.1172/JCI10842

8 Perry RJ, Samuel VT, Petersen KF and Shulman GI: The role of hepatic lipids in hepatic insulin resistance and type 2 diabetes. Nature 510(7503): 84-91, 2014. PMID: 24899308. DOI: $10.1038 /$ nature 13478

9 Wilding JP: The importance of free fatty acids in the development of Type 2 diabetes. Diabet Med 24(9): 934-945, 2007. PMID: 17725706. DOI: 10.1111/j.1464-5491.2007.02186.x

10 Gao D, Nong S, Huang X, Lu Y, Zhao H, Lin Y, Man Y, Wang $\mathrm{S}$, Yang $\mathrm{J}$ and Li J: The effects of palmitate on hepatic insulin resistance are mediated by NADPH Oxidase 3-derived reactive oxygen species through JNK and p38MAPK pathways. J Biol Chem 285(39): 29965-29973, 2010. PMID: 20647313. DOI: 10.1074/jbc.M110.128694

11 Yang M, Wei D, Mo C, Zhang J, Wang X, Han X, Wang Z and Xiao H: Saturated fatty acid palmitate-induced insulin resistance is accompanied with myotube loss and the impaired expression of health benefit myokine genes in $\mathrm{C} 2 \mathrm{C} 12$ myotubes. Lipids Health Dis 12: 104, 2013. PMID: 23866690. DOI: 10.1186/ 1476-511X-12-104 
12 Hatcher H, Planalp R, Cho J, Torti FM and Torti SV: Curcumin: from ancient medicine to current clinical trials. Cell Mol Life Sci 65(11): 1631-1652, 2008. PMID: 18324353. DOI: 10.1007/s00018-008-7452-4

13 Rahmani AH, Alsahli MA, Aly SM, Khan MA and Aldebasi YH: Role of curcumin in disease prevention and treatment. Adv Biomed Res 7: 38, 2018. PMID: 29629341. DOI: 10.4103/abr.abr_147_16

14 Vallianou NG, Evangelopoulos A, Schizas N and Kazazis C: Potential anticancer properties and mechanisms of action of curcumin. Anticancer Res 35(2): 645-651, 2015. PMID: 25667441.

15 Arun $\mathrm{N}$ and Nalini N: Efficacy of turmeric on blood sugar and polyol pathway in diabetic albino rats. Plant Foods Hum Nutr 57(1): 41-52, 2002. PMID: 11855620. DOI: 10.1023/ a:1013106527829

16 Babu PS and Srinivasan K: Hypolipidemic action of curcumin, the active principle of turmeric (Curcuma longa) in streptozotocin induced diabetic rats. Mol Cell Biochem 166(12): 169-175, 1997. PMID: 9046034. DOI: 10.1023/ a:1006819605211

17 Pari L and Murugan P: Antihyperlipidemic effect of curcumin and tetrahydrocurcumin in experimental type 2 diabetic rats. Ren Fail 29(7): 881-889, 2007. PMID: 17994458. DOI: 10.1080/ 08860220701540326

18 Kostrzewa T, Przychodzen P, Gorska-Ponikowska M and KubanJankowska A: Curcumin and cinnamaldehyde as PTP1B inhibitors with antidiabetic and anticancer potential. Anticancer Res 39(2): 745-749, 2019. PMID: 30711953. DOI: 10.21873/ anticanres. 13171

19 Hsieh MT, Chang LC, Hung HY, Lin HY, Shih MH, Tsai CH, Kuo SC and Lee KH: New bis(hydroxymethyl) alkanoate curcuminoid derivatives exhibit activity against triple-negative breast cancer in vitro and in vivo. Eur J Med Chem 131: 141-151, 2017. PMID: 28319780. DOI: 10.1016/j.ejmech.2017.03.006

20 Chang LC, Hsieh MT, Yang JS, Lu CC, Tsai FJ, Tsao JW, Chiu YJ, Kuo SC and Lee KH: Effect of bis(hydroxymethyl) alkanoate curcuminoid derivative MTH-3 on cell cycle arrest, apoptotic and autophagic pathway in triple-negative breast adenocarcinoma MDA-MB-231 cells: An in vitro study. Int J Oncol 52(1): 67-76, 2018. PMID: 29138806. DOI: 10.3892/ ijo.2017.4204

21 Bajaj P, Reddy B Jr, Millet L, Wei C, Zorlutuna P, Bao G and Bashir R: Patterning the differentiation of $\mathrm{C} 2 \mathrm{C} 12$ skeletal myoblasts. Integr Biol (Camb) 3(9): 897-909, 2011. PMID: 21842084. DOI: $10.1039 / \mathrm{c} 1 \mathrm{ib} 00058 \mathrm{f}$

22 Yang JS, Lin CA, Lu CC, Wen YF, Tsai FJ and Tsai SC: Carboxamide analog ITR-284 evokes apoptosis and inhibits migration ability in human lung adenocarcinoma A549 cells Oncol Rep 37(3): 1786-1792, 2017. PMID: 28098885. DOI: 10.3892/or.2017.5374

23 Mehlem A, Hagberg CE, Muhl L, Eriksson U and Falkevall A: Imaging of neutral lipids by oil red $\mathrm{O}$ for analyzing the metabolic status in health and disease. Nat Protoc 8(6): 11491154, 2013. PMID: 23702831. DOI: 10.1038/nprot.2013.055

24 Zou C, Wang Y and Shen Z: 2-NBDG as a fluorescent indicator for direct glucose uptake measurement. J Biochem Biophys Methods 64(3): 207-215, 2005. PMID: 16182371. DOI: 10.1016/ j.jbbm.2005.08.001

25 Yang JS, Lee CY, Cho HC, Lu CC, Kuo SC, Wen YF, Tsai FJ, Lee MR and Tsai SC: ITR 284 modulates cell differentiation in human chronic myelogenous leukemia K562 cells. Oncol Rep 39(1): 383391, 2018. PMID: 29138846. DOI: 10.3892/or.2017.6090

26 Tsai SC, Tsai MH, Chiu CF, Lu CC, Kuo SC, Chang NW and Yang JS: AMPK-dependent signaling modulates the suppression of invasion and migration by fenofibrate in CAL 27 oral cancer cells through NF-kB pathway. Environ Toxicol 31(7): 866-876, 2016. PMID: 25545733. DOI: 10.1002/tox.22097

27 Settembre C, De Cegli R, Mansueto G, Saha PK, Vetrini F, Visvikis O, Huynh T, Carissimo A, Palmer D, Klisch TJ, Wollenberg AC, Di Bernardo D, Chan L, Irazoqui JE and Ballabio A: TFEB controls cellular lipid metabolism through a starvation-induced autoregulatory loop. Nat Cell Biol 15(6): 647-658, 2013. PMID: 23604321. DOI: $10.1038 / \mathrm{ncb} 2718$

28 Sun J, Lu H, Liang W, Zhao G, Ren L, Hu D, Chang Z, Liu Y, Garcia-Barrio MT, Zhang J, Chen YE and Fan Y: Endothelial TFEB (Transcription Factor EB) improves glucose tolerance via upregulation of IRS (Insulin Receptor Substrate) 1 and IRS2. Arterioscler Thromb Vasc Biol 41(2): 783-795, 2021. PMID: 33297755. DOI: 10.1161/ATVBAHA.120.315310

29 Berger J and Moller DE: The mechanisms of action of PPARs. Annu Rev Med 53: 409-435, 2002. PMID: 11818483. DOI: 10.1146/annurev.med.53.082901.104018

30 Kintscher U and Law RE: PPARgamma-mediated insulin sensitization: the importance of fat versus muscle. Am J Physiol Endocrinol Metab 288(2): E287-E291, 2005. PMID: 15637349. DOI: 10.1152/ajpendo.00440.2004

31 Fujita H, Shimizu K and Nagamori E: Novel method for fabrication of skeletal muscle construct from the $\mathrm{C} 2 \mathrm{C} 12$ myoblast cell line using serum-free medium AIM-V. Biotechnol Bioeng 103(5): 1034-1041, 2009. PMID: 19350625. DOI: 10.1002/bit. 22318

32 Lawson MA and Purslow PP: Differentiation of myoblasts in serum-free media: effects of modified media are cell linespecific. Cells Tissues Organs 167(2-3): 130-137, 2000. PMID: 10971037. DOI: $10.1159 / 000016776$

33 Chaturvedi V, Dye DE, Kinnear BF, van Kuppevelt TH, Grounds MD and Coombe DR: Interactions between skeletal muscle myoblasts and their extracellular matrix revealed by a serum free culture system. PLoS One 10(6): e0127675, 2015. PMID: 26030912. DOI: 10.1371/journal.pone.0127675

34 Rimington RP, Capel AJ, Chaplin KF, Fleming JW, Bandulasena $\mathrm{HCH}, \mathrm{Bibb} \mathrm{RJ}$, Christie SDR and Lewis MP: Differentiation of bioengineered skeletal muscle within a $3 \mathrm{D}$ printed perfusion bioreactor reduces atrophic and inflammatory gene expression. ACS Biomater Sci Eng 5(10): 5525-5538, 2019. PMID: 33464072. DOI: 10.1021/acsbiomaterials.9b00975

35 Yamaguchi A: Regulation of differentiation pathway of skeletal mesenchymal cells in cell lines by transforming growth factorbeta superfamily. Semin Cell Biol 6(3): 165-173, 1995. PMID: 7548856. DOI: $10.1006 /$ scel.1995.0023

36 Hoca M, Becer E and Vatansever HS: The role of resveratrol in diabetes and obesity associated with insulin resistance. Arch Physiol Biochem: 1-7, 2021. PMID: 33719825. DOI: 10.1080/ 13813455.2021.1893338

37 Yaribeygi H, Maleki M, Sathyapalan T, Jamialahmadi T and Sahebkar A: Obesity and insulin resistance: a review of molecular interactions. Curr Mol Med 21(3): 182-193, 2021. PMID: 32787760. DOI: 10.2174/1566524020666200812221527

38 Swarup S, Goyal A, Grigorova Y and Zeltser R: Metabolic syndrome. Treasure Island, FL, USA, Statpearls, 2021. 
39 Stuttgen GM and Sahoo D: FFAR4: A new player in cardiometabolic disease? Endocrinology 162(8): bqab111, 2021. PMID: 34043793. DOI: 10.1210/endocr/bqab111

40 Marušić M, Paić $M$, Knobloch $M$ and Liberati Pršo AM: NAFLD, insulin resistance, and diabetes Mellitus Type 2. Can J Gastroenterol Hepatol 2021: 6613827, 2021. PMID: 33681089. DOI: $10.1155 / 2021 / 6613827$

41 Desoye G and Herrera E: Adipose tissue development and lipid metabolism in the human fetus: The 2020 perspective focusing on maternal diabetes and obesity. Prog Lipid Res 81: 101082, 2021. PMID: 33383022. DOI: 10.1016/j.plipres.2020.101082

42 da Paixão AO, Bolin AP, Silvestre JG and Rodrigues AC: Palmitic acid impairs myogenesis and alters temporal expression of miR133a and miR-206 in C2C12 myoblasts. Int J Mol Sci 22(5): 2748, 2021. PMID: 33803124. DOI: 10.3390/ijms22052748

43 Kauffman EC, Ricketts CJ, Rais-Bahrami S, Yang Y, Merino MJ, Bottaro DP, Srinivasan R and Linehan WM: Molecular genetics and cellular features of TFE3 and TFEB fusion kidney cancers. Nat Rev Urol 11(8): 465-475, 2014. PMID: 25048860. DOI: $10.1038 /$ nrurol.2014.162

44 Junkin KA, Dyck DJ, Mullen KL, Chabowski A and Thrush AB: Resistin acutely impairs insulin-stimulated glucose transport in rodent muscle in the presence, but not absence, of palmitate. Am J Physiol Regul Integr Comp Physiol 296(4): R944-R951, 2009. PMID: 19193939. DOI: 10.1152/ajpregu.90971.2008

45 Nieuwoudt S, Mulya A, Fealy CE, Martelli E, Dasarathy S, Naga Prasad SV and Kirwan JP: In vitro contraction protects against palmitate-induced insulin resistance in $\mathrm{C} 2 \mathrm{C} 12$ myotubes. Am J Physiol Cell Physiol 313(5): C575-C583, 2017. PMID: 28835436. DOI: 10.1152/ajpcell.00123.2017

46 Cheema U, Yang SY, Mudera V, Goldspink GG and Brown RA: $3-\mathrm{D}$ in vitro model of early skeletal muscle development. Cell Motil Cytoskeleton 54(3): 226-236, 2003. PMID: 12589681. DOI: $10.1002 / \mathrm{cm} .10095$

47 Berry A, Collacchi B, Masella R, Varì R and Cirulli F: Curcuma Longa, the "Golden Spice" to counteract neuroinflammaging and cognitive decline-what have we learned and what needs to be done. Nutrients 13(5): 1519, 2021. PMID: 33946356. DOI: 10.3390/nu13051519

48 Fallahi F, Borran S, Ashrafizadeh M, Zarrabi A, Pourhanifeh MH, Khaksary Mahabady M, Sahebkar A and Mirzaei H: Curcumin and inflammatory bowel diseases: From in vitro studies to clinical trials. Mol Immunol 130: 20-30, 2021. PMID: 33348246. DOI: 10.1016/j.molimm.2020.11.016

49 Zhang S, Asghar S, Yu F, Hu Z, Ping Q, Chen Z, Shao F and Xiao Y: The enhancement of $\mathrm{N}$-acetylcysteine on intestinal absorption and oral bioavailability of hydrophobic curcumin. Eur J Pharm Sci 154: 105506, 2020. PMID: 32763460. DOI: 10.1016/j.ejps.2020.105506

50 Feng J, Huang M, Chai Z, Li C, Huang W, Cui L and Li Y: The influence of oil composition on the transformation, bioaccessibility, and intestinal absorption of curcumin in nanostructured lipid carriers. Food Funct 11(6): 5223-5239, 2020. PMID: 32458895. DOI: 10.1039/d0fo00473a

51 Chiu YJ, Tsai FJ, Bau DT, Chang LC, Hsieh MT, Lu CC, Kuo SC and Yang JS: Next generation sequencing analysis reveals that MTH 3, a novel curcuminoid derivative, suppresses the invasion of MDA MB 231 triple negative breast adenocarcinoma cells. Oncol Rep 46(1): 133, 2021. PMID: 34013378. DOI: 10.3892/or.2021.8084
52 Sardiello M: Transcription factor EB: from master coordinator of lysosomal pathways to candidate therapeutic target in degenerative storage diseases. Ann N Y Acad Sci 1371(1): 3-14, 2016. PMID: 27299292. DOI: 10.1111/nyas.13131

53 Napolitano G and Ballabio A: TFEB at a glance. J Cell Sci 129(13): 2475-2481, 2016. PMID: 27252382. DOI: 10.1242/ jcs. 146365

54 Medina DL and Ballabio A: Lysosomal calcium regulates autophagy. Autophagy 11(6): 970-971, 2015. PMID: 26000950. DOI: $10.1080 / 15548627.2015 .1047130$

55 Decressac $M$ and Björklund A: TFEB: Pathogenic role and therapeutic target in Parkinson disease. Autophagy 9(8): 12441246, 2013. PMID: 23715007. DOI: 10.4161/auto.25044

56 Song JX, Liu J, Jiang Y, Wang ZY and Li M: Transcription factor EB: an emerging drug target for neurodegenerative disorders. Drug Discov Today 26(1): 164-172, 2021. PMID: 33099023. DOI: 10.1016/j.drudis.2020.10.013

$57 \mathrm{Xu} \mathrm{J}$, Zhang XQ and Zhang Z: Transcription factor EB agonists from natural products for treating human diseases with impaired autophagy-lysosome pathway. Chin Med 15(1): 123, 2020. PMID: 33292395. DOI: 10.1186/s13020-020-00402-1

58 Ikari S, Lu SL, Hao F, Imai K, Araki Y, Yamamoto YH, Tsai CY, Nishiyama Y, Shitan N, Yoshimori T, Otomo T and Noda T: Starvation-induced autophagy via calcium-dependent TFEB dephosphorylation is suppressed by Shigyakusan. PLoS One 15(3): e0230156, 2020. PMID: 32134989. DOI: 10.1371/ journal.pone .0230156

59 Soukas AA and Zhou B: Surviving starvation simply without TFEB. PLoS Biol 17(5): e3000285, 2019. PMID: 31136567. DOI: $10.1371 /$ journal.pbio.3000285

60 Settembre $\mathrm{C}$ and Ballabio A: TFEB regulates autophagy: an integrated coordination of cellular degradation and recycling processes. Autophagy 7(11): 1379-1381, 2011. PMID: 21785263. DOI: $10.4161 /$ auto.7.11.17166

61 Yoo J, Jeong IK, Ahn KJ, Chung HY and Hwang YC: Fenofibrate, a PPAR $\alpha$ agonist, reduces hepatic fat accumulation through the upregulation of TFEB-mediated lipophagy. Metabolism 120: 154798, 2021. PMID: 33984335. DOI: 10.1016/j.metabol.2021.154798

62 Evans TD, Zhang X, Jeong SJ, He A, Song E, Bhattacharya S, Holloway KB, Lodhi IJ and Razani B: TFEB drives PGC-1 $\alpha$ expression in adipocytes to protect against diet-induced metabolic dysfunction. Sci Signal 12(606): eaau2281, 2019. PMID: 31690633. DOI: 10.1126/scisignal.aau2281

63 Verma NK, Singh J and Dey CS: PPAR-gamma expression modulates insulin sensitivity in $\mathrm{C} 2 \mathrm{C} 12$ skeletal muscle cells. $\mathrm{Br}$ J Pharmacol 143(8): 1006-1013, 2004. PMID: 15504754. DOI: 10.1038/sj.bjp.0706002
Received July 7, 2021

Revised July 31, 2021

Accepted August 5, 2021 